\begin{abstract}
Background: Traditionally adjustment to a serious injury such as spinal cord injury has been conceptualised as staged grieving process. Hope in this tradition is commonly defined as denial and considered counterproductive to positive adjustment. These concepts were challenged as the author observed the strength of clients' hope in the face of extremely confronting physical, social and environmental challenges following spinal cord injury.

Purpose: This paper presents qualitative data about the role of hope from the perspective of the person with spinal cord injury and considers the theoretical and clinical aspects of hope in the coping process.

Method: This data presented is a subset of data from a ten year longitudinal year study of a sample of 46 people with spinal cord injury. Semi structured qualitative interviews were conducted at discharge from hospital, six, 12, 24, 36 months post discharge and again at ten years post discharge.

Results: $73 \%$ of the participants identified hope as an essential factor that helped them cope following their injury. Three main foci of hope emerged from the data set: 1 . Hope for a complete recovery; 2 .Hope for a cure; 3 .Hope for a satisfying quality of life.

Conclusion: Hope emerged as a strong theme in the overall adjustment and coping process. Clinical implications for working with people who sustain spinal cord injury are discussed. It is recommended that interventions which support and facilitate hope need to be developed and tested.
\end{abstract}

Keywords: hope; coping; adjustment; disability; spinal cord injury 


\section{The Importance of Hope in Coping with Severe Acquired Disability}

'Hope is the only good that is common to all men; those that have nothing else possess hope still.' Thales of Miletus

The motivating power of hope in the lives of clients in a spinal cord injuries rehabilitation setting has had a profound impact on my practice. The clients were people who had recently sustained a spinal cord injury $(\mathrm{SCl}) . \mathrm{SCl}$ is a devastating injury resulting in permanent paralysis, wheelchair dependence and changes in most bodily functions and life roles.

When I first began working in $\mathrm{SCl}$ rehabilitation I regularly received referrals to see clients who were entrenched in denial. However, I often found a person who had recently sustained a SCl and who was clinging to the hope that their situation would somehow improve, while at the same time fully engaged in a rehabilitation program to prepare for life with $\mathrm{SCl}$. I was reflecting on hope versus denial when I had a pivotal experience while facilitating an educational program for people with recently acquired SCI. I had invited a person who had sustained a SCI many years previously to come and share his experiences. One of the group participants asked the visiting speaker if he ever thought about walking again. The speaker responded "there is never a day that passes that I don't think about walking". He added "not that I really think I ever will but I always think about it." Inwardly I cringed. As the social worker facilitating this group I felt it was important for the participants to come to terms with what had happened to them and in part this involved accepting that they would not walk again.

In all aspects the visiting speaker was a person I considered to be well adjusted. He had been highly successful in both business and sporting arenas since sustaining his injury. He was married and had adopted children. He had a positive outlook on life and the future. His response caused me to ask how could a person be well adjusted and at the same time continue thinking about (or hoping for) 
something that was physically impossible. These experiences challenged me to reflect on what I thought about coping and positive adjustment.

Both my traditional social work education and the prevailing literature suggested that it was important for clients with a severe acquired disability such as $\mathrm{SCl}$ to work through a staged process of grieving to come to terms with their losses (see Dorsett \& Fronek, 2007; Garske \& Turpin, 1998 for critiques of stage theories of adjustment). In contrast I found that hope was a common expression in my clients. I found myself encouraging hope, often in the face of opposition from other rehabilitation professionals who felt it was important for clients to 'confront reality'. Intuitively it seemed that hope was the very thing that gave clients the motivation to keep moving forward with their lives. Consequently I found myself reflecting on some searching questions: Was it valid to be encouraging and supporting clients' hopes or could this approach be problematic for long-term adjustment; if hope was an a positive adaptive response how could one best support hope in clients; and could one assist clients without hope to develop hope. In light of the prevailing literature and attitudes of rehabilitation staff, I needed to consider the possibility that the hope I was encouraging in my clients could in fact be counterproductive to long-term adjustment.

\section{Literature review}

$\mathrm{SCl}$ is a traumatic injury, which typically occurs suddenly and without warning. Treatment and rehabilitation usually require lengthy periods of hospitalisation (Go, DeVivo, \& Richards, 1995). The consequences of $\mathrm{SCl}$ are enormous and affect every aspect of a person's life. Paralysis results in wheelchair dependence and a person with $\mathrm{SCl}$ may be dependent on others for assistance with tasks of daily living such as bathing, toileting, dressing, eating, community access and recreational activities. Bowel, bladder and sexual function are usually impaired (Glass, 1999). There are a number of indicators that the adjustment process can be problematic particularly in the first few years following injury. Depression, divorce and suicide rates are greater than those reported in the general 
population for the first 3-5 years following SCl (Craig, Hancock, Dickson, \& Chang, 1997; DeVivo, Hawkins, Richards, \& Go, 1995; DeVivo \& Richards, 1996; Elliott \& Frank, 1996; Frankel et al., 1998; Hartkopp, Bronnum-Hansen, Seidenschnur, \& Biering-Sorensen, 1997; Kennedy, Rogers, Speer, \& Frankel, 1999; P Kennedy \& Rogers, 2000; Kewman \& Tate, 1998; Rintala, Young, Spencer, \& Bates, 1996; Soden et al., 2000). People with SCI report lower quality of life compared to non-disabled people but quality of life seems to improve over time (Boswell, Dawson, \& Heininger, 1998; Dijkers, 1997; Evans et al., 1994; Krause, 1998). These indicators suggest that the person with $\mathrm{SCl}$ has an increased risk of adjustment difficulties and their coping strengths may be challenged particularly in the early stages following injury.

Since the 1960s stage theories of adjustment have dominated the literature about adjustment to chronic illness and disability (Garske \& Turpin, 1998; Trieschmann, 1988). Stage theories of adjustment tend to be based on concepts adapted from grief and loss psychology or mental health fields (Garske \& Turpin, 1998; Trieschmann, 1988; Wortman \& Silver, 1991) and typically progress through a series of stages including: shock, denial, depression, anxiety, anger, and finally culminate in adjustment (Garske \& Turpin, 1998). Stage theories suggest that depression and grief are necessary prerequisites for satisfactory adjustment (Buckelew, Frank, Elliott, Chaney, \& Hewett, 1991; Keany \& Glueckauf, 1993; Kerr \& Thompson, 1972; Trieschmann, 1988).

Prior to the 1990s, much of the research into adjustment following SCI tended to pathologise the adjustment process rather than identify factors that promote positive adjustment (Dunn, 1995). The field of positive psychology has the potential to identify gaps in this knowledge and assist us to support clients in ways that are respectful of their strengths, courage, and determination in the face of significant life challenges (Seligman \& Csikszentmihalyi, 2000; Snyder \& Lopez, 2002). The appraisals made by the individual in understanding and reconstructing meaning are critical following an injury such as $\mathrm{SCl}$ to understand the adjustment process and factors that are amenable to 
intervention (Elliott, Kurylo, \& Rivera, 2002; Elliott \& Richards, 1999; Elliott \& Sherwin, 1997). Hope has emerged as a key component of appraisal and reconstruction of meaning following $\mathrm{SCl}$.

So what is this thing called hope?

In the literature there is a great deal of ambiguity about how hope is conceptualized. There are many and varied definitions ranging from wishful thinking to sophisticated well developed theoretical constructs. Traditionally hope has been considered a soft concept (Farran, Herth, \& Popivich, 1995). Yet hope is a basic, fundamental and integral part of life. Hope is a common and universal activity for all humans. It has been said that where there is no hope, life ceases (Frankel, 1984). Common hopes are focused on relationships, families, careers, quality of life, financial security and so on. Hope seems to be related to the ability to find meaning in life.

The prevailing literature highlights four key components of hope:

- Hope is focused on the future

- Hope anticipates that the future will be better than the present

- Hope has both cognitive and affective aspects

- The hopeful person believes that the object of their hope can be realised (Elliott et al., 2002; Farran, Herth, \& Popivich, 1995; Kwon, 2002; Snyder, 2000; Snyder, llardi, Michael, \& Cheavens, 2000).

Clinical observation suggests there are however, individual differences in the levels of hopefulness especially in challenging situations such as SCl. This in turn begs the question "Can hope be cultivated, enhanced or supported"? If so what are the practice implications for social workers working with persons who have sustained severe debilitating injuries. To begin to answer these questions it is important to consider the current theoretical understandings of hope. Within the 
positive psychology field interest in the role of hope has been growing but it has not featured to date in research about adjustment to disability or rehabilitation.

Two theoretical perspectives on hope are particularly relevant in addressing these questions. They were the conceptualisation of hope developed by Dufault and Martocchio (1985) and Snyder's Hope Theory (Snyder, 1993; Snyder, Cheavens, \& Sympson, 1997; Snyder et al., 1991; Snyder, llardi, Michael, \& Cheavens, 2000; Snyder, Rand, \& Sigmon, 2002). These theories offer explanations of the role of hope in the coping process as well as suggestions for hope enhancing interventions.

One of the earliest models of hope highlighted the need to understand the role and nature of hope in illness (Dufault \& Martocchio, 1985). Default and Martocchio conceptualised hope as being composed of two spheres: particularised hope and generalised hope. Particularised hope is focused on specific hope objects, while generalised hope is seen as a broad outlook that makes life worthwhile but remains abstract in its focus (Dufault \& Martocchio, 1985).

In this model generalised hopes become more evident when:

- Particular hopes are threatened

- Particular hopes are abandoned because of high uncertainty or rapidly changing circumstances (Dufault \& Martocchio, 1985)

It is as if generalised hope provides a protective environment for the hoping person when particular hopes are compromised or no longer seems realistic. Generalised hope is conceptualised as a buffer, providing comfort and a sense of safety from which particular hopes can be later developed (Dufault \& Martocchio, 1985). This model provides a sound understanding of the role of hope in the coping process.

A second conceptualisation of hope is proposed by Synder and colleagues (Snyder, 1993; Snyder et al., 1997; Snyder et al., 1991; Snyder et al., 2000; Snyder et al., 2002). The Snyder model provides clinical utility in the development of hope enhancing interventions. This model proposes that hope 
'reflects the belief that one can find a way to realise desired goals (i.e. pathways) and become motivated to use those pathways (i.e. agency)' (Snyder, Rand, \& Sigmon, 2002). Snyder's model has been widely researched and interventions derived from this model have been tested in a variety of fields such as academic achievement, sport, and palliative care (Snyder, 1993, 2000; Snyder et al., 2000; Snyder, Sympson, Michael, \& Cheavens, 2001; Snyder et al., 1996). Snyder's model of hope has been referred to as a trilogy of hope consisting of 3 basic aspects; goals, pathways and agency (Kwon, 2002). According to Snyder's theory the goals must be perceived to be attainable but may also contain a component of uncertainty.

Pathways are defined as the belief that one can find a way to reach a desired goal and involves being able to formulate at least one practical means to achieve the desired goal (Snyder et al., 1997; Snyder et al., 2002). It is suggested that pathway thinking is particularly important when there are obstacles to the goal. When goal achievement is blocked the development of alternative routes becomes imperative. Research indicates that people with high levels of hope believe that they are capable of finding alternative ways and can be very effective at creating alternative routes. (Snyder, Ilardi, Mitchell, \& Cheavens, 2000)

In the Synder model agency is the extent to which people believe in their capacity to implement action to achieve the desired goal. Agency is conceptualised as providing the motivation for a person's goal pursuits. Agency thoughts are typified by self talk which affirms that 'I can do this' 'I am not going to be stopped' and become particularly important when people encounter impediments to goal achievement (Snyder et al., 2002). 
Some theorists see hope as an emotion. Snyder has clearly defined it as a cognitive process and proposes that positive emotions flow from the perception of successful goal pursuit. Negative emotions on the other hand flow from impeded or unsuccessful goal pursuits. Thus Snyder argues that emotions are the results of goal-directed thought (Snyder et al., 2002). If this is the case then hope enhancing interventions could have a positive impact on low mood in clients who are struggling with challenging situations such as $\mathrm{SCl}$.

Positive adaptive benefits of hope

Hope theory provides a framework for understanding and enhancing adaptive ways of functioning and coping. A substantial body of literature is emerging which confirms positive adaptive benefits of hope in a wide variety of settings. These findings are summarised in Table 1.

\section{[Insert Table 1]}

There is some evidence suggesting that in challenging or difficult times those who have high levels of hope may become more goal orientated thus providing an alternative pathway to overcome the challenges confronted. Snyder suggests that for these individuals goal orientated thinking seems to become more prominent when the going gets tough (Snyder et al., 1997). Conversely those with low levels of hope may become disillusioned and give up.

It is recognized that hopelessness is a reliable predictor of suicide risk (Russinova, 1999). Therefore hope enhancing interventions may be an effective preventative approach to minimise suicide risk. Hope provides a reason to go on living, helps maintain motivation, positive expectations and may mediate the effect of depression. Russinova (1999) suggests that in the context of life threatening situations hope may function as a lifesaving force for individuals who are overwhelmed by despair. 
Many clients with $\mathrm{SCl}$ achieve good adjustment outcomes however there is a smaller sub-group who do not do so well. Increasingly it is was important to listen more closely to the stories of the client to gain insights into 'how' people cope and adjust and how to better assist those who are not doing so well. These concerns and the desire to learn from the lived experience of clients were the impetus to investigate the coping process following severe acquired disability such as $\mathrm{SCl}$.

To develop greater insight into the coping and adjustment trajectory following $\mathrm{SCl}$ a ten year longitudinal study of people who had sustained a SCl was undertaken. The purpose of the study was to explore the impact of $\mathrm{SCl}$ on the individual, the ways in which people react to and cope with $\mathrm{SCl}$ and describe psychosocial outcomes over time. The study included both quantitative and qualitative methodologies. Outcomes from psychological, health and environmental life domains were measured and included variables such as depression, life satisfaction, vocational, medical complications, hospital readmissions, financial and access to aids and equipment. The qualitative data about hope which is presented in this article is small subset of the qualitative data generated from the larger study (Dorsett \& Geraghty 2008; Dorsett, 2005; Dorsett \& Geraghty, 2004).

\section{Methodology}

\section{Participants}

The sample comprised all adults with acute traumatic SCl consecutively discharged from the Spinal injuries Unit of the Queensland Spinal Cord Injuries Service following the initial hospitalisation episode. A total of 53 patients met the inclusion criteria over the 12 month recruitment period. Fiftyone individuals (96\%) agreed to participate in the study.

Five (10\%) individuals were from an indigenous background were eventually dropped from the sample because the data collection methods proved culturally inappropriate for this subgroup, leaving a final sample of 46 individuals. 
Demographics and injury characteristics of the participant group presented in Table 2 indicates that age, gender, cause and type of injury are consistent with the trends in $\mathrm{SCl}$ populations reported in Australian (O'Connor \& Cripps, 1998)and international literature (Stover, DeLisa, \& Whiteneck, 1995).

\section{Procedures}

Ethics

All procedures were approved and monitored by the Human Research Ethics Committee of the relevant institution. Informed consent was obtained from participants.

Design

A longitudinal mixed method design was used to collect data over ten years. There were six data collection points; at discharge from hospital $(n=46)$ at 6 months $(n=44), 12$ months $(n=40), 24$ months $(n=35), 36$ months $(n=33)$ and 10 years post discharge $(n=32)$. At each interview, a structured quantitative questionnaire and a semi-structured qualitative interview were administered at each data collection point. Findings from the larger study are reported elsewhere (Dorsett \& Geraghty 2008; Dorsett, 2005; Dorsett \& Geraghty, 2004).

The qualitative aspects of this study adopted a life history style qualitative interview (Minichiello, Aroni, Timewell, \& Alexander, 1995). This style of interviewing facilitates greater understanding of the process of adjustment from the viewpoint of the individual, their interpretations of and how their perception of that reality changes over time. Over the ten year course of this study a total of 220 interviews were conducted. At each interview the participant was asked to relate their story and how it had evolved since the last interview. Prompts were introduced into the flow of the story 
telling to encourage respondents to talk about: the changes the $\mathrm{SCl}$ had caused in their lives, difficulties encountered, their expectations of the future, the things that helped and/or made it difficult to cope. Each respondent was asked "What advise would you offer to someone else going though a similar situation?". The researcher was particularly interested in the adjustment trajectory and things that impacted on that process from the participants' perspective. The data was analysed progressively identifying themes and developing concepts that contributed to adjustment from the perspective of the person with $\mathrm{SCl}$ using the NVivo Qualitative Data Package. The data being presented in this article is a small subset of the qualitative data. The theme of hope emerged from the data as an important factor contributing to the coping process from the client's perspective.

\section{Findings}

What do people with SCl think about hope?

Thirty-two (70\%) of the 46 people who participated in this study clearly articulated that maintaining hope was an essential factor that helped them cope in the early stages following their injury. For many participants hope continued to be an important factor in coping with the long-term consequences of their injuries. This theme of hope emerged strongly from the data despite the fact that no questions in the interview directly addressed the concept of hope. Questions such as "What was the most important thing that helped you get through this experience?" or "If you were talking to someone who had recently been injured, what advice would you offer?" often evoked strong statements about hope or 'never giving up'.

Three main foci of hope emerged from the data set. First, respondents hoped for a full and complete recovery (i.e. to walk again). From a medical perspective this would be an unrealistic expectation and often equated with denial of the reality of the circumstances. Second, the respondents held hopes that were focused on the possibility of a cure from which they would be able to benefit in the future. Given the positive indicators of current medical research it is increasingly likely that a cure 
for $\mathrm{SCl}$ may be discovered. Potential cures are likely to be of more benefit to those injured more recently and therefore may be of little or no benefit to those participating in this study who have now been injured more than 10 years. Third, the respondents held hopes that were focused on quality of life. There was evidence that hopes to walk were more firmly held in the earlier stages post injury. Hopes focused on a potential cure and quality of life were more common as time since injury increased.

Hope initially provided the motivation to survive and get on with life. Hope was a strong motivator. The respondents who had incomplete $\mathrm{SCl}$ (i.e. some preserved sensation or movement albeit often limited) had more reason to cling to hope for continued physical recovery. For some there was an element of realism about their hope because doctors often advise people with incomplete $\mathrm{SCl}$ that recovery can continue for up to two years post injury. They are however, usually cautioned that it is rare to get complete recovery and that the longer one goes without recovery the less likely it is that recovery will occur. Popular books about recovery following $\mathrm{SCl}$ often place emphasis on the need to work hard and maintain a positive attitude, fuel these hopes (Shepherd, 1996). Such books often imply that if you do these two things you are guaranteed recovery. The present climate of expectancy in relation to a potential cure for $\mathrm{SCl}$ gives further reason to remain optimistic (Wright et al., 2008).

Hope for Recovery

Hope for recovery was strongest in the early stages post injury and was sometimes maintained even when the respondents knew it is was a remote possibility. The statement below was made by a respondent with complete $\mathrm{SCl}$ at 6 months post discharge from hospital and reflects the hope to walk again.

"Don't ever give up. I still think one day I'll walk again - maybe not the same as before but I still think it will happen." (ID1: 6 months) 
Another respondent with an incomplete $\mathrm{SCl}$ made this statement 3 years post-discharge, when from a medical perspective the chance of any further recovery was remote.

"I'm getting some sensation (feeling) back in my upper leg. I think I'll keep getting more back. It's not normal feeling, like direct feeling, but I can tell there are changes. There is more feeling there but no movement in the muscles. You have to keep hoping and waiting." (ID2: 36 months).

These statements highlight the capacity to maintain hope to walk again in tension with the growing realisation that this may be increasingly unlikely. Many respondents expressed similar hopes focused on walking again in the early stages post $\mathrm{SCl}$.

For some respondents hope continued to be maintained, despite the progressive realisation that the focus of their hope may not be fully realised. This is evidenced by the following data from one individual's interview transcripts over the ten-year period. These statements were made by a female respondent who had an incomplete quadriplegia level injury. She remained wheelchair dependent although she could stand briefly with a great deal of effort. Her hands were weak and she required assistance with most self-care activities. In the early stages post $\mathrm{SCl}$ her focus was firmly on recovery:

"I really appreciated the small things as I began to do things for myself. Being able to turn pages. Being able to get my own cigarettes out of the packet. Seeing things coming back kept me going. The recovery kept giving me hope." (ID22: 6 months).

However by 12 months post discharge from hospital there is evidence of a level of uncertainty starting to creep in, although the hope for recovery is still evident.

"I still haven't come to terms with what has happened to me yet. I'm still counting down for my two years. I know I have to accept it." (ID22: 12 months). 
While all of her hope was firmly pinned on recovery in the early stages by the $2^{\text {nd }}$ year her capacity to maintain that hope was being challenged although not abandoned.

"I'm still hoping for a full recovery. - I have to keep hoping and keep trying. I have to keep exercising." (ID22: 24 months).

There was a sense of desperate clinging to hope in tension with an emerging realisation that the hope may not be achieved. It was as if there was an internal battle to resist giving in to the increasing realisation that she may not attain the level of recovery she initially hoped for. There is also a sense that if she stays positive and works hard enough her hope will be realised.

By the third year however her focus was starting to shift and was now more focused on the "good things in life". Elsewhere in the interview this respondent indicated that the "good things in life" from her perspective were about relationships with her family and quality of life.

"A lot of people need to see that there is a pot of gold at the end of the rainbow- Not just money but good things in life." (ID22: 36 months).

However by the $10^{\text {th }}$ year the focus of her hope had clearly shifted. She talked about the need to accept her paralysis and the importance of quality of life. In the same interview she also related an incident about searching for information about research into a cure. The focus of her hope at the $10^{\text {th }}$ year was directed towards a cure and life satisfaction as demonstrated in the quote below. She continues to espouse the need to maintain a positive attitude and a fighting spirit.

"Oh, there's always light at the end of the tunnel, just at least have a go...and think positive not negative. I know it's pretty hard like to sometimes accept but down the track you learn to accept it. You've still got to fight, you know, life still goes on... Yeah like the Aussie thing,

'have a go mate'. " (ID22: 10 years) 
The data from this respondent demonstrates the changing foci of hope over the course of the 10 years. This trajectory moving from hope firmly focused on walking to hopes focused on cure and quality of life were reflected in the data from many of the participants.

The tension between hope and uncertainty

Even where the hope to walk was strongly established some respondents experienced periods of doubt which resulted in despondency. For example this young man with incomplete paraplegia speaks about his wavering hope. He did not achieve walking and remained wheelchair dependent. He experienced significant periods of depression and readjustment of his hope goals over the ten year study. By the 10th year he had firmly established hopes for a quality of life based on his ability to generate income and follow through with an investment plan that he was implementing. His hope goals essentially changed from walking to other foci such as financial security. His capacity to shift his hope focus over time is significant.

At his discharge from hospital he said:

I'm very positive about the future. Positive plus, plus, plus about walking again. It may take some time - like about a year or two but I know I'll get there. I'll be 99\% normal again in time. (ID25: Discharge)

At 6 months post-discharge interview he was depressed because of the lack of progress in achieving his hope to walk again and struggling to redefine meaning in his life:

"I get very depressed at times especially about walking. I keep asking why did this happen to me? I know it's happened and that I can't turn back the clock. I know that other people are worse off than me. I can't change the past. I have to look to the future but I still get periods of depression. When I get depressed I just mope around the house then something good happens and pulls me out of my depression." (ID25: 6 Months) 
By his tenth year post injury his hopes are clearly focused on quality of life issues.

"I am working up to a planned future. Even though I don't have a lot of income I'm still saving. I plan to buy my own home when I'm able to" (ID25:10 years)

Hope in the face of reality

Even those respondents who had complete injuries and were aware that medically there was really no hope of recovery were able to maintain hope.

"I think about walking sometimes but I don't really think I ever will again. But I still believe in miracles." (ID31).

There were many examples of this type of hope in the face of reality, particularly in the first year post discharge. Traditionally using hope as a strategy to cope has been interpreted as denial. Denial may have a place to play in coping with SCl. Lazarus and Folkman (1991) suggest that where there is little opportunity or ability to change an extreme situation then denial may be an effective coping mechanism. There is much debate about the role and effectiveness of denial in the coping process. Timothy Elliot provides a more complete discussion of this debate (Elliot, Witty, Herrick, \& Hoffman, 1991; Elliott \& Sherwin, 1997).

Hope for a cure

The second foci which emerged from the data was the hope for a cure. Currently there is no known cure for SCl but medical research is offering grounds for hope into the future (Wright et al., 2008). For the participants the possibility of a future cure had implications which meant that they needed to exercise to maintain the range of movement in their joints if they were to benefit from a cure if or when it is discovered. 
"I have high hopes of a cure. I've been listening to the radio and reports about the work being done in Japan. There is always a doubt but there is always hope to get more movement back. I have plans for the future. I know I'll never be the same as before therefore I need to keep my mind active so I can do well in the future...I want to make as much money as I can so that if a cure does come along I can afford to go overseas for the treatment. I'm still pretty hopeful." (ID33:10 years).

Hope for a cure also provided the very the motivation to carry on living for some respondents.

"I live in hope of a cure. Otherwise I would get out of life all-together." (ID35:36 months).

For others hope for a cure was not the sole hope but figured quite importantly from the client's perspective.

"I hope that in the future they will develop an operation that will give me a cure. I believe it will happen but I don't let my life revolve around it." (ID37:10 months).

The theme of hope focused on a cure was more common in $10^{\text {th }}$ year interview data.

Hope and life satisfaction

Hope was also an important factor for those individuals who were more realistic about walking. For them hope looked to a future life that could be satisfying to them. The following statement suggests that even at a very early stage hope of a future quality of life can be a motivating factor to get on with life.

"The best thing was getting out of the Edgerton bed (a special bed used to nurse people with $\mathrm{SCl}$ who are immobilised), and then into a chair (wheelchair) and then to physiotherapy. Once I started getting to the gym I knew there was hope. When I was still in bed I didn't want to listen to the other's positive suggestions about what I could achieve." (ID41: Discharge). 
As time since injury increased many respondents talked about hopes clearly anchored to gaols related to quality of life. For example this respondent has goals to move out of the family home, to live with his girlfriend and to gain employment.

"Just take each day as it comes. I aim to get out on my own with my girlfriend. I'm hoping to get a job too." (ID2: 36 months)

Hope and goals

The Dufault and Martocchio (1985) model discussed earlier suggests that generalised hope provides a protective environment for the hoping person when particular hopes are compromised or no longer seems realistic. This was supported in the data as exemplified by this very insightful quote where the role of hope initially provides comfort and a sense of safety from which particular hopes were developed over time.

"... hope is important, very early on it is something you look at and you think, oh, I hope ...the damage isn't as bad as it first seems or, I hope I might be able to walk, or I hope my arms are still going to work all right, so that's a lot of hope... I can see that in the early stages. You know, that's just hoping for the best basically! But after that, I think hope goes to the back of the line, and I think very important is being able to accept what's happened to you and what you've got left...you've got to have active goals that you've got to do to get to it. Just sitting around and saying "I hope this will happen" is not the way to go (ID41:10 years)

This particular respondent had become an elite wheelchair sportsperson and had a very goal centered approach to life. While he made clear distinctions between hope and goals he captures the essence of hope as conceptualized by Martocchio and Default (1985) as he reflected the concept of generalised hope which provided a buffering effect in the early stages but was replaced by 
particularised hopes. Additionally he captures aspects of Synder's (1991) cognitive conceptualisation of hope as being anchored by a goal and finding pathways and motivations to achieve the goal.

The will and the way

Snyder (1991) has suggested that both the will (agency) and the way (pathway) to goal achievement are the defining factors of hope. Agency helps to maintain motivation and explore alternative pathways if necessary as evidenced by this statement from a respondent with a quadriplegia level injury.

"Some days I just make up my mind that I'm going to do something, like tying my shoe laces. I thought about it for a while and worked out how I thought I could do it. Then when I had time I tried it. It took most of the morning the first time. I was all hot and frustrated but I did it. Being stubborn helps I think. Now I do it all the time." (ID30:12 months)

Immediately following injury this respondent was very depressed, refused to participate in a rehabilitation program, withdrew from social contact and became very isolated. As he was encouraged to engage in small tasks his confidence and capacity to see a future developed. Each small success built on his hope and outlook for the future. When interviewed 10 years post injury, he had married, had fathered a child, was employed full-time, obtained his drivers licence and returned to his hobby of racing stock cars. He was positive about the future and often visited the hospital as a peer support volunteer.

\section{Discussion}

Implications for practice

Evidence presented above provides strong theoretical and research evidence to confirm the importance of hope in the adjustment process following a severe acquired disability such as $\mathrm{SCl}$. Based on the findings of this study and emerging evidence in other fields it important that 
interventions which sustain and facilitate hope with an appropriate focus are developed and tested to better support the adjustment process especially with those who are having difficulties. The ability to maintain hope in the face of significant disruption to life, such as the experience following $\mathrm{SCl}$, may be further supported by interventions, which address other psychosocial problems in the social and environmental spheres of life. There is some evidence from this study that the role and focus of hope in the adjustment process following $\mathrm{SCl}$ may change over time. Because hope is both an affective and cognitive coping response, interventions can be targeted at either or both the affective and cognitive arenas.

By its very nature $\mathrm{SCl}$ can generate a sense of hopelessness. It challenges one's sense mastery and control. The person with $\mathrm{SCl}$ becomes dependent, social roles and participation may be reduced, and usual avenues for satisfaction and competence are compromised. The reduction in self efficacy and uncertain prognosis may additionally contribute to a sense of hopelessness which may be intensified by isolation and loss of material resources.

A person's view of their disability, their perceived control over it and their understanding of the long term outcome determine how they will react. In other words the person's appraisals in understanding their unique situation will be a determining factor in their adjustment outcome. The theoretical understanding of hope presented above can assist in developing interventions to support hope development, redefining meaning in life, goal setting and overcoming feelings of helplessness and hopelessness. 
In the context of $\mathrm{SCl}$ social workers can support hope development in clients in the context of an empathetic relationship, and an environment where the client is empowered to resume control over the decisions which affect their life. Good physical care and the management of the physical consequences of $\mathrm{SCl}$ are also crucial. It is very difficult to maintain hope if $\mathrm{SCl}$ symptoms, such as continence or pain are not effectively managed. Physical rehabilitation allows the client to develop skills, knowledge, and confidence to self-manage their condition. These skills, knowledge and confidence contribute to formation of realistic goals and the motivation to pursue desired outcomes. Even in the face of permanent $\mathrm{SCl}$, hope can be engendered through restoration of self esteem and self-efficacy that comes through increased competence and resumption of valued social roles. As the client is assisted to achieve their goals hope for the future will grow.

Social workers can play a key role in the rehabilitation team by providing information, reassurance, exploring meaning and appraisals and the development of problem solving skills. Behavioural interventions which assist the development of a self-efficacy and independent decision making as well as encouraging a re-engagement in social relationships and social or recreational activities assist the client to develop purpose and hope. Interventions which reduce the sense of alienation and reinforce the perception of being valued as a person are important to the maintenance hope. Additionally social workers play a key role in facilitating assess to necessary resources through interventions such as advice, referral and advocacy.

In the initial stages the person with $\mathrm{SCl}$ may have little knowledge about their actual condition. Their initial hope may be activated by a sense of agency in that they may be motivated by goal directed energy and the will to get better (i.e. generalised hope). As time passes and more information is gained, treatment offered, physical competence is developed and future options are explored. These 
may assist the client to engage in strategies to achieve personal goals. A person with a strong sense of hope is more likely to fully engage with the rehabilitation program and meaningful independent living. Generalised hope in the initial stages post injury help to stave off the negative impact of the situation until a clear pathway for action can be found. Social workers can assist clients to set goals, develop motivation and plan ways of achieving these goals. These interventions are crucial to development and maintenance of hope in the early stages (Elliot et al., 1991).

Macro interventions which address the systemic barriers confronted by people with disabilities are significant hope enhancing interventions. People with disabilities are confronted with many barriers and limitations imposed by social, political and cultural systems. These barriers are significant impediments to goal achievement. Many clients with $\mathrm{SCl}$ relate the sense of being in a constant battle to obtain services to meet their basic needs resulting in significant social, physical and financial disadvantage which is draining on both physical and emotional stamina. This constant strain can deplete hopefulness is even the most resilient of clients.

\section{Conclusion}

It should be emphasised that while hope emerged as a significant coping response to $\mathrm{SCl}$, the overall findings from the larger study including both qualitative and quantitative data confirmed that adjustment is a complex process which involves interactions between many life domains. While this article has concentrated on the importance of hope, I would want to distance myself from any simplistic explanation of adjustment or coping that would locate the adjustment process solely within the psychological arena. Clearly there are many social, environmental and health issues that mediate the capacity of the individual coping response including the development of hope. No single explanation adequately explains the coping process. A synthesis of research findings from a range of perspectives is necessary to allow us to develop an adequate understanding of the coping response 
following a traumatic acquired disability such as $\mathrm{SCl}$. If we are to develop an adequate response to support positive adjustment across multiple life domains, social constructs and political influences, an integrated understanding is essential.

The primary concern of this study was to gain an understanding of the processes of adjustment to $\mathrm{SCl}$ over time from the client's perspective. Much of the existing research on adjustment following $\mathrm{SCl}$ has focussed on the initial crisis period immediately following injury or on identifying factors that are predictive of positive outcomes. The question "how successful "copers" go about achieving their success" which remains largely unanswered (MacDonald et al, 1987, p.342). The longitudinal qualitative approach adopted in this study allowed us to capture the unfolding nature of the adjustment process and highlighted the importance of hope in the adjustment process. Theoretical and practice implications for social work have been explored and discussed.

This study leaves us with a number of questions which require further investigation. For example:

- Why does one person respond to $\mathrm{SCl}$ with hope and a positive attitude that result in a renewed sense of purpose and another with despondency and passivity?

- Does hope buffer the negative response to a trauma like SCl thus reducing the likelihood of depression, powerlessness and despair?

- Do people with higher levels of hope achieve more positive long-term adjustment outcomes?

Research in other fields is increasingly indicating that this is the case but to date no research in the rehabilitation field has established these links.

\section{Acknowledgement}

I would like to acknowledge the following:

- The Princess Alexandra Hospital Foundation for a grant to support the final stage of the research 
- The participants who shared their lives so freely

- The Management and staff of the Queensland Spinal Cord Injuries Service and the Princess Alexandra Hospital Social Work Department who provided emotional support and valuable advise 


\section{References}

Back, A. L., Arnold, R. M., \& Quill, T. E. (2003). Hope for the best, and prepare for the worst. Annals of Internal Medicine, 138(5), 439-442.

Boswell, B. B., Dawson, M., \& Heininger, E. (1998). Quality of life as defined by adults with spinal cord injuries. Journal of Rehabilitation, 64(1), 27-32.

Buckelew, S. P., Frank, R. G., Elliott, T. R., Chaney, J., \& Hewett, J. (1991). Adjustment to spinal cord injury: stage theory revisited. Paraplegia, 29(2), 125-130.

Chi, G. C. (2007). The role of hope in patients with cancer Oncology Nursing Forum, 34(2), 415-424.

Clark, D. (2002). Between hope and acceptance: the medicalisation of dying. BMJ, 324(905-907).

Craig, A. R., Hancock, K., Dickson, H., \& Chang, E. (1997). Long-term psychological outcomes in spinal cord injured persons: results of a controlled trial using cognitive behavior therapy. Archives of Physical Medicine and Rehabilitation, 78(1), 33-38.

Curry, L. A., Snyder, C. R., Cook, D. L., Ruby, B. C., \& Rehm, M. (1997). The role of hope in studentathlete performance and sport achievement. Journal of Personality and Social Psychology, 73, 257-267.

Deegan, P. (1988). Recovery: The lived experience of rehabilitation. Psychosocial Rehabilitation Journal, 11(4), 11-19.

DeVivo, M. J., Hawkins, L. N., Richards, J. S., \& Go, B. K. (1995). Outcomes of post-spinal cord injury marriages. Archives of Physical Medicine and Rehabilitation, 76(2), 130-138.

DeVivo, M. J., \& Richards, J. S. (1996). Marriage rates among persons with spinal cord injury. Rehabilitation Psychology, 41(4), 321-339.

Dijkers, M. (1997). Quality of life after spinal cord injury: a meta analysis of the effects of disablement components. Spinal Cord, 35, 829-840. 
Dorsett, P., \& Geraghty, T. J. (2004). Depression and adjustment following spinal cord injury: a three year longitudinal study. Topics in Spinal Cord Injury Rehabilitation, 9(4), 43-56

Dorsett, P. (2005). Spinal cord injury: how do people cope? A ten year longitudinal study (Unpublished Report). Brisbane: Queensland Spinal Cord Injury Service.

Dorsett, P., \& Fronek, P. (2007). Shifting sands: changing the way we thing about practice. SCI Psychosocial Process, 20(1).

Dorsett, P., \& Geraghty , T. (2008). Health-related outcomes of people with spinal cord injury-a 10 year longitudinal study. Spinal Cord(46), 386-391.

Dufault, K., \& Martocchio, B. C. (1985). Hope: its spheres and dimensions. Nursing Clinics of North America, 20(2), 379-391.

Duggleby, W. D., Degner, L., Williams, A., Wright, K., Cooper, D., Popkin, D., et al. (2007). Living with hope: initial evaluation of a psychosocial hope intervention for older palliative home care patients. Journal of Pain and Symptom Management, 33(3), 247-257.

Dunn, D. S. (1995). Well-being following amputation: salutary effects of positive meaning, optimism and control. Rehabilitation Psychology, 41(4), 285-302.

Elliot, T. R., Witty, T. E., Herrick, S., \& Hoffman, J. T. (1991). Negotiating reality after physical loss: hope, depression, and disability. Journal of Personality and Social Psychology, 61(4), 608613.

Elliott, T. R., \& Frank, R. G. (1996). Depression following spinal cord injury. Archives of Physical Medicine and Rehabilitation, 77(8), 816-823.

Elliott, T. R., \& Sherwin, E. D. (1997). Developing hope in the social context: alternative perspectives of motive, meaning, and identity. Group Dynamics: Theory, Research and Practice, 1(2), 119123. 
Elliott, T. R., Kurylo, M., \& Rivera, P. (2002). Positive growth following acquired physical disability. In C. R. Snyder \& S. J. Lopez (Eds.), Handbook of Positive Psychology (pp. 687-699). Oxford: Oxford University Press.

Elliott, T. R., \& Richards, J. S. (1999). Living with the facts, negotiating the terms: unrealsitic beliefs, denial and adjsutment in the first year of acquired disability. Journal of Personal and Interpersonal Loss, 4, 361-381.

Evans, R. L., Hendricks, R. D., Connis, R. T., Haselkorn, J. K., Ries, K. R., \& Mennet, T. E. (1994). Quality of life after spinal cord injury: a literature critique and meta-analysis (1983-1992). Journal of the American Paraplegic Association, 17(2), 60-66.

Farran, C. J., Herth, K. A., \& Popivich, J. M. (1995). Hope and Hopelessness: Critical Clinical Constructs. Thousand Oaks: Sage.

Frankel, H. L., Coil, J. R., Charlifue, S. W., Whiteneck, G. G., Gardner, B. P., Jamous, M. A., et al. (1998). Long-term survival in spinal cord injury: a fifty year investigation. Spinal Cord, 36, 266-274.

Frankel, V. E. (1984). Man's Search for Meaning. New York: Washington Square Press.

Garske, G. G., \& Turpin, J. O. (1998). Understanding psychosocial adjustment to disability: an American perspective. International Journal of Rehabilitation and Health, 4(1), 29-37.

Glass, C. A. (1999). Spinal Cord Injury: Impact and Coping. Leicester: BPS Books (British Psychological Society).

Go, B. K., DeVivo, M., \& Richards, J. (1995). The epidemiology of spinal cord injury. In S. L. Stover, J. DeLisa \& G. Whiteneck (Eds.), Spinal Cord Injury: clinical outcomes from the model systems. Gaithersberg: Aspen Publishers.

Hartkopp, A., Bronnum-Hansen, H., Seidenschnur, A. M., \& Biering-Sorensen, F. (1997). Survival and cause of death after traumatic spinal cord injury. A long-term epidemiological survey from Denmark. Spinal Cord, 35(2), 76-85. 
Hollis, V., Massey, K., \& Jevne, R. (2007). An intentional use of hope. Journal of Allied Health, 36(1), $52-56$.

Keany, K. C., \& Glueckauf, R. L. (1993). Disability and value change: an overview and reanalysis of acceptance of loss theory. Rehabilitation Psychology, 38, 199 - 210.

Kennedy, P., Rogers, B., Speer, S., \& Frankel, H. (1999). Spinal cord injuries and attempted suicide: a retrospective review. Spinal Cord, 37(12), 847-852.

Kennedy, P., \& Rogers, B. A. (2000). Anxiety and depression after spinal cord injury: A longitudinal analysis. Archives of Physical Medicine and Rehabilitation, 81(7), 932 -937.

Kewman, D. G., \& Tate, D. G. (1998). Suicide in SCI: A psychological autopsy. Rehabilitation Psychology, 43(2), 143-151.

Kerr, W., \& Thompson, M. (1972). Acceptance of disability of sudden onset in paraplegia. Paraplegia, 10, 94-102.

Krause, J. S. (1998). Subjective well-being after spinal cord injury: relationship to gender, raceethnicity, and chronologic age. Rehabilitation Psychology, 43(4), 282-296.

Kwon, P. (2002). Hope, defense mechanisms and adjustment: implications for false hope and defensive hopelessness. Journal of Personality, 70(2), 207-231.

Maikranz, J. M., Steele, R. G., Dreyer, M. L., Stratman, A. C., \& Bovaird, J. A. (2007). The relationship of hope and illness-related uncertainty to emotional adjustment and adherence among renal and liver transplant recipents. Journal of Pediatric Psychology, 32(5), 571-581.

Minichiello, V., Aroni, R., Timewell, E., \& Alexander, L. (1995). In-Depth Interviewing: Principles, Techniques, Analysis (2nd ed.). Melbourne: Longman.

O'Connor, P., \& Cripps, R. (1998). Spinal Cord Injury, Australia 1997/98 (No. AlHW Cat. No. INJ19): Research Centre for Injury Studies, Flinders University.

Onwuegbuzie, A. J., \& Snyder, C. R. (2000). Relationship between hope and graduate students' studying and test-taking strategies. Psychological Reports, 86, 803-806. 
Rintala, D. H., Young, M. E., Spencer, J. C., \& Bates, P. S. (1996). Family relationships and adaptation to spinal cord injury: a qualitative study. Rehabilitation Nursing, 21(2), 67-74, 90.

Russinova, Z. (1999). Providers' hope inspiring competence as a factor optimizing psychiatric rehabilitation outcomes. The Journal of Rehabilitation, 65(4), 50-.

Seligman, M. E., Csikszentmihalyi, M. (2000). Positive psychology: an introduction. American Psychologist, 55(1), 5-14.

Snyder, C. R. (1993). Hope for the journey. In A. P. Turnbull, J. M. Patterson, S. K. Behr, D. L. Murphy, J. G. Marquis \& M. J. Blue-Banning (Eds.), Cognitive Coping, Families, and Disability (pp. 271286). Baltimore: Paul Brookes Publishing Co.

Snyder, C. R. (1999). Hope, goal-blocking thoughts, and test-related anxieties. Psychological Reports, 84, 206-208.

Snyder, C. R. (Ed.). (2000). Handbook of Hope: Theory, Measures and Applications. San Diego: Academic Press.

Snyder, C. R., Cheavens, J., \& Sympson, S. C. (1997). Hope: an individual motive for social competence. Group Dynamics: Theory, Research and Practice, 1(2), 107-118.

Snyder, C. R., Harris, C., Anderson, J. R., Holleran, S. A., Irving, L. M., Sigmon, S. T., et al. (1991). The will and the ways: development and validation of an individual-differences measure of hope. Journal of Personality and Social Psychology, 60(4), 570-585.

Snyder, C. R., Ilardi, S., Michael, S. T., \& Cheavens, J. (2000). Hope theory: updating a common process for psychological change. In C. R. Snyder \& R. E. Ingram (Eds.), Handbook of Psychological Change: Psychotherapy Processes and practices for the 21st Century. New York: John Wiley \& Sons.

Snyder, C. R., \& Lopez, S. J. (Eds.). (2002). Handbook of Positive Psychology. Oxford: Oxford University Press. 
Snyder, C. R., Rand, K. L., \& Sigmon, S. T. (2002). Hope theory: a member of the positive psychology family. In C. R. Snyder \& S. J. Lopez (Eds.), Handbook of Positive Psychology (pp. 257-276). Oxford: Oxford University Press.

Snyder, C. R., Sympson, S. C., Michael, S. E., \& Cheavens, J. (2001). Optimism and hope constructs: variants on a positive expectancy theme. In E. C. Chang (Ed.), Optimism \& Pessimism: Implications for Theory, Research, and Practice (pp. 101-123). Washington DC: American Psychologcal Association.

Snyder, C. R., Sympson, S. C., Ybasco, F. C., Borders, T. F., Babyak, M. A., \& L, H. R. (1996). Development and validation of the state hope scale. Journal of Personality and Social Psychology, 70(2), 321-335.

Soden, R. J., Walsh, J., Middleton, J. W., Craven, M. L., Rutkowski, S. B., \& Yeo, J. D. (2000). Causes of death after spinal cord injury. Spinal Cord, 38(10), 604-610.

Stover, S. L., DeLisa, J. A., \& Whiteneck, G. G. (1995). Spinal Cord Injury: Clinical Outcomes from the Model Systems. Gaithersburg, Maryland: Aspen Publishers.

Taylor, S. E., \& Brown, J. D. (1994). Positive illusions and well-being revisited: separating fact from fiction. Psychological Bulletin, 116(1), 21-27.

Taylor, S. E., Kemeny, M. E., Bower, J. E., Gruenewald, T. L., \& Reed, G. M. (2000). Psychological resources, positive illusions and health. American Psychologist, 55(1), 99-109.

Trieschmann, R. B. (1988). Spinal Cord Injuries: Psychological, Social and Vocational Rehabilitation (Second ed.). New York: Demos.

Wortman, C. B., \& Silver, R. C. (1991). The myths of coping with loss. In A. Monat \& R. S. Lazarus (Eds.), Stress and Coping: An Anthology (3 ed.). New York: Columbia University Press.

Wright, K. T., Osman, A., Roberts, S., Trivedi, J., Ashton, B. A., et al. (2008). The cell culture expansion of bone marrow stromal cells from humans with spinal cord injury: implications for future cell transplantation therapy. Spinal Cord, 46, 811-817. 
Table 1: Summary of hope research findings

\begin{tabular}{|c|c|c|}
\hline Area & Findings & Source \\
\hline $\begin{array}{l}\text { Academic } \\
\text { performance }\end{array}$ & $\begin{array}{l}\text { Students with high hope scores tend to } \\
\text { have better academic achievement, even } \\
\text { controlling for intellectual ability and self- } \\
\text { esteem. Students with low hope tend to } \\
\text { experience high anxiety in examinations. } \\
\text { High hope students are more likely to } \\
\text { effective use feedback to improve } \\
\text { performance. }\end{array}$ & $\begin{array}{l}\text { (Onwuegbuzie \& Snyder, } \\
\text { 2000; Snyder, 1999) }\end{array}$ \\
\hline $\begin{array}{l}\text { Athletic } \\
\text { performance }\end{array}$ & $\begin{array}{l}\text { Those who are more hopeful are more } \\
\text { successful in athletic competition even } \\
\text { when controlling for physical ability. }\end{array}$ & $\begin{array}{l}\text { (Curry, Snyder, Cook, Ruby, } \\
\text { \& Rehm, 1997) }\end{array}$ \\
\hline $\begin{array}{l}\text { Interpersonal life } \\
\text { satisfaction }\end{array}$ & $\begin{array}{l}\text { People with higher hope report greater } \\
\text { levels of interpersonal life satisfaction. }\end{array}$ & \\
\hline Physical health & $\begin{array}{l}\text { People with higher level of hopes are more } \\
\text { motivated to utilise self-management } \\
\text { strategies and health promoting } \\
\text { behaviours. }\end{array}$ & $\begin{array}{l}\text { (Chi, 2007; Hollis, Massey, } \\
\text { \& Jevne, 2007; Maikranz, } \\
\text { Steele, Dreyer, Stratman, \& } \\
\text { Bovaird, 2007) }\end{array}$ \\
\hline Mental illness & $\begin{array}{l}\text { People with mental illness identify hope as } \\
\text { one the most important determinates of } \\
\text { recovery. }\end{array}$ & $\begin{array}{l}\text { (Deegan, 1988; Farran et } \\
\text { al., 1995) }\end{array}$ \\
\hline Palliative care & $\begin{array}{l}\text { Knowing that one is dying but hoping to } \\
\text { live are not incompatible. Hope has been } \\
\text { found to contribute to a greater sense of } \\
\text { control over the disease, higher quality of } \\
\text { life and better coping outcomes. }\end{array}$ & $\begin{array}{l}\text { (Back, Arnold, \& Quill, } \\
\text { 2003; Clark, 2002; } \\
\text { Duggleby et al., 2007; } \\
\text { Taylor \& Brown, 1994; } \\
\text { Taylor, Kemeny, Bower, } \\
\text { Gruenewald, \& Reed, 2000) }\end{array}$ \\
\hline Goal achievement & $\begin{array}{l}\text { Research consistently shows that people } \\
\text { with high hope are more likely to attain } \\
\text { their goals than people with low hope even } \\
\text { when intelligence and physical ability are } \\
\text { controlled for. This suggests that hope is } \\
\text { not just a consequence of goal attainment } \\
\text { but is actually a facilitator of goal }\end{array}$ & (Snyder et al., 1997) \\
\hline
\end{tabular}




\begin{tabular}{|c|c|c|}
\hline & $\begin{array}{l}\text { attainment. l.e. if two people are equal in } \\
\text { ability but unequal in hope the person with } \\
\text { high hope will out achieve the person with } \\
\text { low hope. }\end{array}$ & \\
\hline $\begin{array}{l}\text { Psychological } \\
\text { problems }\end{array}$ & $\begin{array}{l}\text { People with high hope scores report less } \\
\text { severe psychological problems and a more } \\
\text { positive outlook concerning problems in } \\
\text { their lives. } \\
\text { Higher levels of hope have been linked to } \\
\text { more positive mood outcomes. }\end{array}$ & $\begin{array}{l}\text { (Carifo \& Rhodes, 2002) } \\
\text { (Kwon, 2002) }\end{array}$ \\
\hline Goal centeredness & $\begin{array}{l}\text { People with high hope tend to select } \\
\text { numerous and more difficult/ challenging } \\
\text { goals and tend to break their goals down } \\
\text { into smaller sub-goals. They can clearly } \\
\text { conceptualise goals while persons with low } \\
\text { hope are more vague and ambiguous } \\
\text { about their goals. }\end{array}$ & $\begin{array}{l}\text { (Snyder et al., 1997) } \\
\text { (Carifo \& Rhodes, 2002) }\end{array}$ \\
\hline Self-efficacy & $\begin{array}{l}\text { Subjects with high hope scores also tended } \\
\text { to report greater confidence in their ability } \\
\text { to solve problems and a broader range of } \\
\text { problem solving skills." }\end{array}$ & (Carifo \& Rhodes, 2002) \\
\hline
\end{tabular}


Figure 2: Participant demographic and injury characteristics $(N=46)$

\begin{tabular}{|l|r|}
\hline Demographic and injury characteristics & Number (\%) \\
\hline Gender & $42(91 \%)$ \\
Male & $4(9 \%)$ \\
Female & \\
\hline Age at injury, years & $11(24 \%)$ \\
$16-19$ & $15(31 \%)$ \\
$20-29$ & $9(20 \%)$ \\
$30-39$ & $3(6 \%)$ \\
$40-49$ & $4(9 \%)$ \\
$50-59$ & $4(9 \%)$ \\
$60+$ & $16-72$ years \\
Range & 32 years (27) \\
Mean (median) & $19(41 \%)$ \\
\hline Level of injury & $27(59 \%)$ \\
Paraplegia & $16(35 \%)$ \\
Quadriplegia & $30(65 \%)$ \\
\hline Degree of impairment & \\
Complete & $20(44 \%)$ \\
Incomplete & $7(15 \%)$ \\
\hline Aetiology & $9(20 \%)$ \\
Road trauma & $2(4 \%)$ \\
Falls & $8(17 \%)$ \\
Sports/recreational activities & \\
Acts of violence & \\
Other & \\
\hline
\end{tabular}

